\title{
РІШЕННЯ ПРОБЛЕМНИХ ПИТАНЬ ПРИ ВПРОВАДЖЕННІ ОСНОВНИХ ПОЛОЖЕНЬ ЄКТС У ВНМУ ІМ. М. І. ПИРОГОВА
}

\author{
В. М. Мороз, Ю. Й. Гумінський, Л. В. Фоміна, Т. Л. Полеся \\ Вінницький національний медичний університет імені М. І. Пирогова
}

\section{SOLUTION OF THE PROBLEM QUESTIONS AT INTRODUCTION OF THE FUNDAMENTAL PRINCIPLES OF ECTS IN VINNYTSIA NATIONAL MEDICAL UNIVERSITY BY M. I. PYROHOV}

\author{
V. M. Moroz, Yu. Y. Huminskyi, L. V. Fomina, T. L. Polesya \\ Vinnytsia National Medical University by M. I. Pyrohov
}

\begin{abstract}
У зв'язку з європейською інтеграцісю України та підписанням Болонської конвенції з 2005 року у вищих навчальних закладах запроваджена кредитно-модульна система навчання. 32009 року для вищих навчальних закладів с обов'язковим запровадження основних положень свропейської кредитно-трансферної системи (СКТС) та її ключових документів. Аналіз недоліків та переваг навчання при кредитно-модульній системі виявив протиріччя між основними вимогами СКТС та їх реалізацією. У зв'язку з коадаптацією національної системи освіти до вимог свропейських стандартів у ВНМУ ім. М. І. Пирогова запропоновані зміни підходів щодо організації навчального процесу у світлі кредитно-модульної системи.
\end{abstract}

In connection with European integration of Ukraine in the Bologna idea convention from 2005 year the credit-transfer educational system for the higher institutions is introduced. From 2009 for the higher educational establishments introduction of fundamental principles of the European credit-transfer system (ECTS) and its basic documents are obligatory. Analysis of defects and advantages of studies by credit-transfer system exposed contradiction between ECTS and its realization. In connection with the coadaptation of the national system of education to the requirements of the European standards in Vinnytsia National Medical University by M. I. Pyrohov there was proposed the change of ways of the relation to organization of educational process in the idea of the credittransfer system.

Вступ. Процес об’єднання Європи супроводжується формуванням спільного освітнього і наукового простору та розробкою єдиних критеріїв і стандартів у всіх сферах, в тому числі й в освітній, що й було задекларовано Україною в основних документах Болонських угод [1]. Головна мета Болонського процесу - інтеграція зусиль наукової та освітянської громадськості й урядів країн Європи для істотного підвищення конкурентоспроможності європейської системи науки і вищої освіти у світовому вимірі. На всіх етапах підписання угод було проголошено, що цей процес $є$ добровільним, полісуб'єктивним, багатоваріантним, грунтується на цінностях європейської освіти та культури, а також враховує і зберігає національні особливості освітніх систем різних країн Свропи. Одним з інструментів реалізації цілей Болонського процесу є запровадження європейської кредитнотрансферної системи (ЄКТС), яка допомагає вищим навчальним закладам досягти забезпечення якості освіти у світлі євроінтеграції.

Основна частина. Реформування медичної вищої освіти полягає у коадаптації національної та європейсь- кої систем вищої освіти, що має оптимізувати якість підготовки фахівців на рівні міжнародних вимог [6]. Згідно наказами МОН та МОЗ України з 2005-2006 навчального року у ВНМУ ім. М. І. Пирогова впроваджено кредитно-модульну систему навчання (КМC), як одну з форм реалізації основних положень Болонських угод. Основою КМС є модульне викладання дисциплін, надання кредитів дисциплінам та зарахування їх успішним студентам, рейтингова система оцінювання знань студентів за шкалою ECTS та конвертація оцінки в традиційну систему за чотирибальною шкалою. Разом з цим згідно з наказом МОН України № 943 від 16. 10. 09 та листом МОН України № 1/9-119 від 26.02.10 у всіх вищих навчальних закладах України запроваджена Європейська кредитнотрансферна система (СКТС), метою якої є забезпечення якості вищої освіти та інтеграція національної системи вищої освіти в європейське та світове освітнє співтовариство. ЄКТС передбачає запровадження стандартів, рекомендацій та основних інструментів мобільності для студентів і викладачів Європейського простору вищої освіти. Відповідно до вимог Євро-

() В. М. Мороз, Ю. Й. Гумінський, Л. В. Фоміна, Т. Л. Полеся 
пейської кредитно-трансферної системи, базовими ключовими документами для вищих навчальних закладів є наявність Каталогу курсів, Аплікаційної форми студента, Угоди про навчання, Угоди про практичну підготовку та зобов'язання про якість, Академічної довідки, Додатка до диплома європейського зразка [2]. Для університетів ЄКТС створює прозорість навчальних планів, у яких відображена інформація про зміст навчального процесу, надає допомогу при узгодженні програм навчання мобільним студентам, відображає результати навантаження та навчання, разом 3 цим забезпечує автономію вузам та відповідальність за якість навчання студента. СКТС є системою накопичення кредитів, орієнтованою на особу, що навчається, та включає опис кредитів, їх перезарахування іншими вузами - партнерами, шкалу ранжування оцінок у системі ECTS та їх конвертацію у національну шкалу. Використання ЄКТС є обов'язковою вимогою при акредитації освітніх програм та навчальних закладів. ЄКТС передбачає самостійність вищого навчального закладу у формуванні компонентів навчального плану, встановлення кредитів вибіркової частини змісту освіти, а також можливість обирати форми контролю знань студентів, в тому числі іспит. В Довіднику користувача СКТС визначена позиція щодо форм підсумкового контролю з дисциплін, які не виключають такі методи контролю, як іспити. СКТС передбачає розрахунок навантаження студента та розподіл кредитів з дисциплін (лекцій, практичних, семінарських, лабораторних занять, консультацій, в тому числі й на екзаменаційнупідготовку), а на контрольні заходиу вигляді іспитів виділяється один кредит. Слід відмітити, що планування графіка навчального процесу та розкладу навчальних занять, тривалості теоретичного навчання та екзаменаційної сесії $є$ прерогативою вищого навчального закладу, що не заперечує положенням ЄКТС. Для виставлення екзаменаційних оцінок, залікових оцінок (усі заліки диференційовані), захистів, звітів з практики використовується розширена шкала підсумкового контролю. Оцінки за цією шкалою заносяться до відомостей обліку успішності, залікових книжок (індивідуальних навчальних планів) студентів та іншої академічної документації. ЄКТС дає можливість користуватись будь-якою шкалою оцінювання, проте доцільним є врахування раніше накопиченого досвіду. Таким чином, організація навчального процесу у всіх вищих навчальних закладах України, в тому числі і медичних, проводиться за кредитно-модульною системою (КМС) та базується на основних положеннях європейської кредитно-трансферної системи (EKTC).
Аналіз 7-річного досвіду впровадження КМС у ВНМУ ім. М. І. Пирогова виявив іiі переваги та недоліки порівняно з традиційною системою навчання. Перевагами кредитно-модульної системи навчання $\epsilon$ підвищення мотивації студентів до навчання, контроль викладача при опануванні практичних навичок та вмінь на кожному занятті, впровадження 7-бальної рейтингової шкали ECTS, що відображає білыш об' єктивне оцінювання успішності студентів, значна активізація та оновлення методично-навчального забезпечення - створення нових Типових програм, нових методично-навчальних посібників, тематичних збірників тестів, ситуаційних задач тощо. Відбулись оновлення сайтів університету та кафедр, на яких розміщені всі навчально-методичні матеріали, що дає змогу студентам застосовувати інноваційне дистанційне навчання та значно активізувати самостійну роботу. Разом з позитивними змінами при впровадженні КМС слід відмітити недоліки, які полягають у відсутності затверджених МОН України нового Положення про впровадження КМС у ВН3, уніфікованої нормативно-звітної документації, Положення про нарахування стипендій; деканати та кафедри перевантажені новими формами звітної документації, що часто дублює одна одну; співвідношення викладачстудент 1:5 не відповідає дійсності, відсутня університетська клініка, викладачі кафедр мають велике годинне навантаження. Відповідно до планів практичних занять у відділеннях лікарень на клінічних базах часто бракує тематичних хворих, що ускладнює оцінювання теоретичних та практичних знань студентів на кожному занятті. Збільшена кількість студентів у групах на клінічних базах та невеликі приміщення в палатах лікарень не покращують взаємостосунків студентів та пацієнтів, що заважає опануванню практичних навичок та професійних вмінь. Одною з головних причин перешкод в реалізації основних положень КМС є недостатнє фінансування вищої медичної освіти, наслідком яких є складнощі у матеріально-технічному оснащенні та недостатнє стимулювання праці викладачів. Для оптимізації та покращення якості медичної освіти з оглядом на чисельні протиріччя при реалізації основних положень КМС у ВНМУ ім. М. І. Пирогова були запропоновані та затверджені Вченою радою університету зміни в організації навчального процесу:

1. Згідно з новими планами виробничу практику студенти повинні були проходити впродовж навчального року на клінічних базах лікарень. Враховуючи специфіку проходження виробничої практики, університет виступив ініціатором повернення виробничої 
лікарської практики студентів 4 та 5 курсів по закінченні весняного семестру, відповідно робочою групою надані пропозиції при створенні Типової програми з проведення виробничої практики.

2. Змінені підходи щодо конвертації традиційних поточних оцінок в бали для оптимізації та уніфікації конвертації оцінок. Для всіх дисциплін введена єдина універсальна шкала перерахунку традиційних оцінок 35 бальної системи у європейську бальну шкалу оцінювання. Слід відмітити, що раніше вага балів, отриманих студентом з різних дисциплін та модулів, що конвертувалися 3 традиційної 5-бальної шкали оцінювання, була різною залежно від кількості занять у кожному модулі, тому уніфікація оцінювання успішності студентів значно зменшує кількість помилок при арифметичному підрахуванні балів викладачами.

3. Запроваджено єдину залікову книжку для студентів всіх факультетів очної форми навчання (індивідуальний план студента розрахований на 6 років навчання), яка містить обов'язкову інформацію про результати всіх видів успішності.

4. Кафедрам, що викладають дисципліни з предметів ліцензійних тестових іспитів “Крок-1" та “Крок2”, надано завдання розробити навчальні плани та програми, адаптовані для введення у 2012-2013 навчальному році класичних комісійних іспитів. Оцінка знань 3 модулів не залишає у студента загального уявлення про відповідний предмет та не сприяє отриманню довгострокових системних знань. Модульне оцінювання не стимулює студента до усвідомлення програмного матеріалу з дисциплін в цілісному сприйнятті. Питома вага поточного оцінювання (60 \%) контролюється викладачем (іноді з малим педагогічним стажем), а підсумковий контроль знань 3 модуля контролюється досвідченими екзаменаторами (лише 40 \% від загальної суми балів), тобто контроль знань студентів викладачем переважає на поточних заняттях з дисциплін. Адаптація до КМС полягає у проведенні поточного модульного контролю у звичайний спосіб - класичні заліки (відповідно до модулів), що оцінюються за шкалою “120/80”, та класичного іспиту. Такі форми контролю оцінювання знань не порушують основні принципи СКТС.

Проведені додаткові контрольні заходи у зимову сесію у вигляді класичних іспитів висвітлили пози- тивну сторону змін в організації навчального процесу, наприклад, зменшена кількість академічної заборгованості (за результатами зимової сесії відповідно у 2011/2012 н. р. академічну заборгованість мали $17,54 \%$ студентів, а у 2012/2013 н. р. після проведення іспитів - 11,42\%), збільшено контроль успішності студентів з боку деканатів, підвищені відповідальності кафедр за результати своєї роботи, контроль завідувача кафедри за якістю викладання, усвідомлення відповідальності з боку студентів, підвищення конкурентності та мотивації серед студентів щодо оцінювання результатів навчання (на тлі останнього розподілу).

Висновки. Аналіз 7-річного впровадження КМС віддзеркалює складний процес оптимізації та складні шляхи впровадження кредитно-модульної системи навчання при реформуванні вищої медичної освіти. Дослідження показали, що з часом відбувається коадаптація національних та інноваційних модульних технологій навчання. Кожен навчальний заклад в країнах Свропи використовує свої методології та підходи організації навчання, при реалізації основних принципів та положень ЄКТС $[3,4]$. За своєю сутністю кредитно-модульна система навчання не тотожна європейській кредитно-трансферній системі, а є одною 3 багатьох форм та інструментів реалізації СКТС. Нова концепція реформування вищої медичної школи України полягає у запровадженні різних форм організації навчального процесу, в тому числі й введення додаткових форм контролю знань студентів у вигляді іспитів, головне завдання - зберегти архітектуру СКТС (наявність трансферу накопичувальних кредитів, ключових документів, статистична шкала оцінок ECTS та їх конвертація у національну шкалу). Головна мета впровадження СКТС - гармонізація національних освітніх систем вищої освіти в країнах Європи з метою підвищення конкурентоспроможності ВН3 [5]. Крок за кроком поступово удосконалюються шляхи реформування вищої медичної освіти в України згідно з європейськими стандартами [6]. Вищі навчальні заклади країн Свропи реформують свою освіту в національних рамках, але мають виконувати задекларовані Болонськими угодами зобов’ язання у світлі основних положень європейської кредитно-трансферної системи.

\section{Лiтература}

1. Визначення критеріїв якості в системі безперервного професійного розвитку лікарів та провізорів на основі концепції кредитів / Ю. В. Вороненко, А. М. Сердюк [та ін.] // Медична освіта. -2007.-№ 3.-С. 11-15.

2. Довідник користувача ЄКТС 2009. Брюссель, 6 лютого 2009 p. - http://www.bologna2009benelux.org; Веб-сторінка секретаріату Болонського процесу, Бенілюкс 2009. - http:/ /www.bologna2009benelux.org. 
3. Комюніке Конференції міністрів європейських країн, відповідальних за сферу вищої освіти (Лондон, 16-19 травня 2007 року). -К., 2008. - Кн. 4 : Основні засади розвитку вищої освіти України. -С. 24-30.

4. Вища медична освіта і Болонський процес : навч.-метод. та інф.-довідк. матеріали наради-семінару для наук.пед. працівників, аспірантів, магістрів (17-19 січня 2005 р.). Частина I. - Київ, 2005. - С. 112-115.
5. Болонский процесс: нарастающая динамика и многообразие (документы международных форумов и мнения европейских экспертов). - М. : Исследовательский центр проблем качества подготовки специалистов, 2002. - С. 231234.

6. Система управління якістю медичної освіти в Україні : монографія / [І. С. Булах, О. П. Волосовець, Ю. В. Вороненко та ін.]. -Д. : АРТ-ПРЕС, 2003. 